\title{
Oral hamartoma with an advanced elevation of the tongue
}

\author{
Yuka Yamada, ${ }^{1}$ Hajime Okita, ${ }^{2}$ Taneaki Nakagawa, ${ }^{1}$ Seiji Asoda (i] ${ }^{1}$
}

${ }^{1}$ Department of Dentistry and Oral Surgery, Keio University School of Medicine, Shinjuku-ku, Tokyo, Japan

${ }^{2}$ Division of Diagnostic Pathology, Keio University School of Medicine, Shinjuku-ku, Tokyo, Japan

\section{Correspondence to}

Dr Seiji Asoda; asoda@keio.jp

Accepted 6 October 2021

\section{DESCRIPTION}

A 4-year-old boy was referred from another hospital without a paediatric department, having the swelling of the tongue, snoring and pronunciation difficulty for the past roughly 10 months. His birth had been uneventful, and he had no remarkable medical history. A tumour was noted on right floor of the mouth, with a little resistance, smooth surface and normal colour (figure 1). His tongue was extremely elevated, causing a speech disorder, uncontrollable dropping of saliva and issues chewing; however, no pain or respiratory distress was apparent. MRI showed heterogeneously contrast enhancement and a mixture of hypointense and hyperintense signals onT1-weighted and T2-weighted imaging (figure 2). Suspecting sarcoma, we conducted a biopsy under general anaesthesia, noting no complications, including bleeding and airway trouble. The lesion was suspected to be a hamartoma, therefore, we performed transoral tumour excision under general anaesthesia, while paying careful attention to the salivary duct. We were able to easily peel the tumour from the oral mucosa and tongue, which was firm. The tumour measured $50 \times 42 \times 35 \mathrm{~mm}$

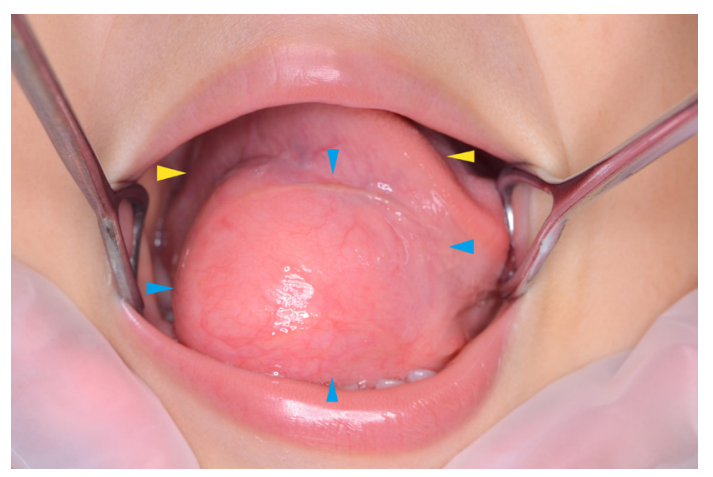

Figure 1 Photograph at the first visit. The tumour (blue arrows) was about $60 \mathrm{~mm}$ in size, located on the right floor of the mouth and elevating the tongue (yellow arrows).

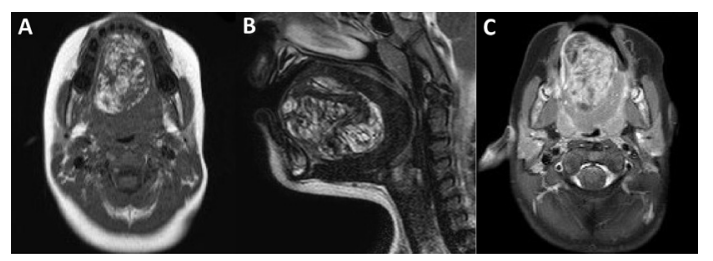

Figure 2 (A) T1-weighted MRI. (B) T2-weighted MRI. (C) Contrast-enhanced, fat-suppressed T1-weighted MRI. The lesion placed extreme pressure on its origin (the tongue) and had clear margins.

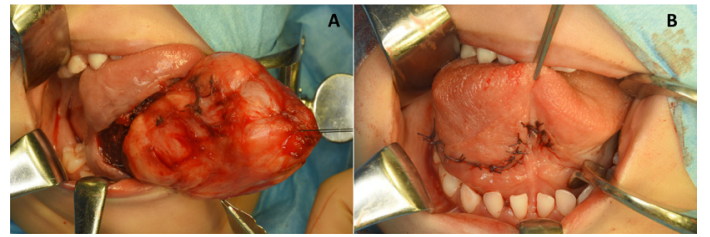

Figure 3 (A) Photograph at the excision. The tumour was covered with a slight membrane and was easily peeled from the oral mucosa and tongue. (B) Photograph after the excision.

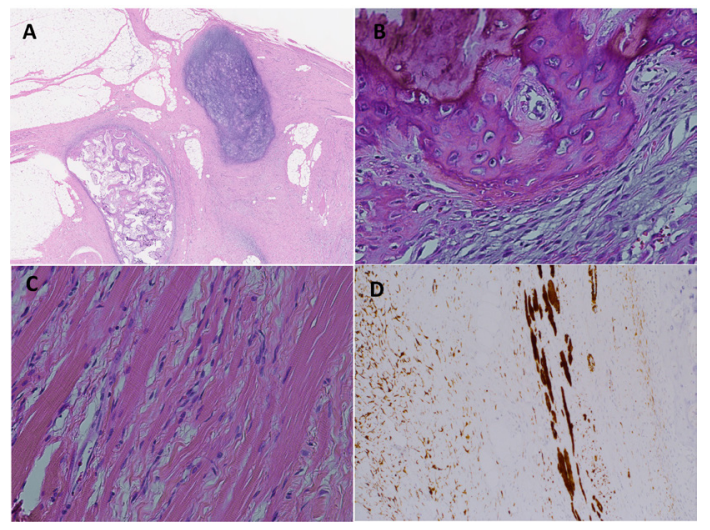

Figure $4 \quad(A-C) H \& E$ staining results. There were mature adipose islands, skeletal muscle and ossification and calcification. (D) Immuonohistochemical positivity for desmin.

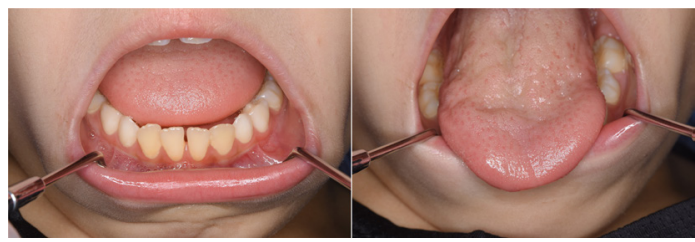

Figure 5 Photograph at 4 years after the excision. There has been no problem for the movement of the tongue.

and had a thin, fibrous membrane (figure $3 \mathrm{~A}$ ). Its cross-section of tumour showed white, yellow and brown structures. Microscopically, there were mainly some mature adipose islands admixed with collagenous stroma and skeletal muscle. Ossification, calcification and smooth muscle fibres were observed very slightly (figure $4 \mathrm{~A}-\mathrm{C}$ ). On immunohistochemistry, desmin positivity was detected in the skeletal muscle bundles (figure 4D). Desmin was also positive in small spindle cells. No epithelium or central nervous system findings were observed, nor was any positivity for AE1/AE3, CK, EMA or MIC2 detected. There were no immature 
elements or malignancy. These results confirmed the diagnosis of hamartoma. The patient tolerated the procedure well and was discharged the following day after uneventful airway observation (figure $3 \mathrm{~B}$ ). There has been no recurrence of the lesion in the 4 years since excision (figure 5 ).

Hamartoma is defined as a tumour-like malformation composed of a focal overgrowth of mature normal cells which were native to the organ of its origin. ${ }^{1}$ It is a congenital lesion and usually asymptomatic, being detected as an incidental mass. Oral hamartoma is rare, and most of cases occur in young children, located on the tongue or the anterior palate. Forty-five oral hamartomas were reported in PubMed from 1990 to 2020 and two of them were located sublingually and one of those was as large as the one described in the present patient. ${ }^{2}$ In our H\&E examination, the skeletal muscles bundles had proliferated, with only slight ossification and calcification observed. Ossification

\section{Learning points}

- Young children tend not to complain of abnormalities, so we should be alert for symptoms such as snoring and pronunciation difficulty.

- When we treat for giant oral tumour, we should check for airway trouble and assess the oral function. was also found in the aforementioned large hamartoma. Because of no abnormality such as cleft palate or bifid tongue, the aetiology of the present tumour was unknown. Painless lesions located on the inner surface may be undetected by patients until growing up. Generally, hamartomas do not recur, but the present tumour was quite large and histologically varied, so multiple mesenchymal cells may have been potentially present. We continue our observations every 6 months to detect any recurrence.

Contributors YY: treated the patient, drafted the manuscript. HO: diagnosed the pathology, drafted the manuscript. TN: drafted the manuscript. SA: treated the patient, drafted the manuscript.

Funding The authors have not declared a specific grant for this research from any funding agency in the public, commercial or not-for-profit sectors.

Competing interests None declared.

Patient consent for publication Consent obtained from parent(s)/guardian(s)

Provenance and peer review Not commissioned; externally peer reviewed.

ORCID iD

Seiji Asoda http://orcid.org/0000-0003-0006-1586

\section{REFERENCES}

1 Albrecht H. Uber hamartome. Verh Dtsch Ges Pathol 1904;7:153.

2 Li J, Mao C, Ma L, et al. Giant sublingual hamartoma with medial cleft tongue: a case report and literature review. J Int Med Res 2020;48:1-6.

Copyright 2021 BMJ Publishing Group. All rights reserved. For permission to reuse any of this content visit

https://www.bmj.com/company/products-services/rights-and-licensing/permissions/

BMJ Case Report Fellows may re-use this article for personal use and teaching without any further permission.

Become a Fellow of BMJ Case Reports today and you can:

- Submit as many cases as you like

- Enjoy fast sympathetic peer review and rapid publication of accepted articles

- Access all the published articles

- Re-use any of the published material for personal use and teaching without further permission

Customer Service

If you have any further queries about your subscription, please contact our customer services team on +44 (0) 2071111105 or via email at support@bmj.com.

Visit casereports.bmj.com for more articles like this and to become a Fellow 